\title{
THE WORLD DRAUGHTS (CHECKERS) CHAMPIONSHIP 1992
}

\author{
London, UK \\ August 17-29, 1992
}

For the first time in history a computer program challenges a human for the World Championship title in a thinking game. From August $17^{\text {th }}-29^{\text {th }}, 1992$, at the Park Lane Hotel in London, Dr. Marion Tinsley (USA) will play a 40-game match against CHINOOK, written by a team at the University of Alberta, headed by ICCA Secretary-Treasurer Jonathan Schaeffer.

For the past 40 years Dr. Tinsley, a mathematics professor from Talahassee, Florida, has reigned supreme in the world of $8 \times 8$ Draughts (Checkers). During that time he lost only a handful of games. CHINOOK earned the right to challenge Tinsley for the World Championship by finishing in second place, behind Tinsley, at the USA National tournament in Petal, Mississippi in 1990. In that tournament all 4 games between CHINOOK and Dr. Tinsley were drawn.

The match in London is being sponsored by Silicon Graphics. CHINOOK was developed on Silicon Graphics hardware at the University of Alberta in Edmonton, and will use an on-site Silicon Graphics multi-processor system in London.

For further details please contact David Levy. Telephone +44 81459 2388. Fax +44 814596422.

\section{A NEW ICCA BOARD}

\section{David Levy}

\section{ICCA President}

At the 1986 ICCA elections a new Board took over the management of our association, having been elected for a 3-year period. At the end of that term there were no other candidates for election and so the entire Board decided to run again, without opposition. Now, after 6 years, we feel that it is time for some changes to be made. At the forthcoming ICCA elections in Madrid, in November, I shall not be a candidate for the post of President. Instead I am supporting the nomination of Tony Marsland, who for the past 6 years has served the ICCA as its Deputy President.

Tony is so well-known in the computer-chess arena that he needs no introduction. He has served the computerchess fraternity very well for more than 20 years and I take great pleasure in announcing that he has agreed to be a candidate for ICCA President. Tony has the full support of the other members of the ICCA Board and I very much hope that our members will also support him.

In stepping down as President I am in no way relinquishing my work for computer chess or for the ICCA. I shall be a candidate for the post of Deputy President and, if elected, I shall continue to search for the sponsors who make our regular events possible and who provide the essential funds to keep the ICCA alive. It is in this area that I believe I can make the most significant contribution.

This year the ICCA is losing its Secretary/Treasurer. Jonathan Schaeffer has held this onerous post for 6 years. In spite of the heavy work involved and the full dedication required, Don Beal has been found willing to assume the duties of Secretary/Treasurer for the next period.

To sum up the sitting Board proposes the election of the following officers:

$\begin{array}{ll}\text { President: } & \text { Tony Marsland } \\ \text { Vice-President: } & \text { David Levy } \\ \text { Secretary/Treasurer: } & \text { Don Beal }\end{array}$

This proposal has been duly received, bearing the signatures of the three Board Members and those of a sufficient number of our members in good standing of the ICCA. Members are advised that alternative proposals may be submitted up to August 27, 1992, each proposal to be signed by five members in good standing and to be accompanied by a declaration of the intent to serve by the person(s) named. 